\title{
ハマトビムシのロコモーション・メカニズム
}

\section{Locomotion Mechanism of Beach Flea}

$\begin{array}{cllllll}\text { O学 } & \text { 天野 } & \text { 拓也（秋田県大） } & \text { 正 } & \text { 須藤 } & \text { 誠一（秋田県大） } \\ \text { 正 } & \text { 白井 } & \text { 敦 } & \text { (東北大) } & \text { 正 } & \text { 早瀨 } & \text { 敏幸 (東北大) }\end{array}$

\author{
Takuya AMANO, Akita Prefectural University, Ebinokuchi 84-4,Yurihonjo, Akita Prefecture 015-0055, Japan \\ Seiichi SUDO, Akita Prefectural University \\ Atsushi SHIRAI, Tohoku University \\ Toshiyuki HAYASE, Tohoku University
}

Key Words: Biomechanics, Fluid Dynamics, Locomotion, Swimming, Jump, Drag, Beach Flea

\section{1. 緒 言}

動物は一般に動きまわって生活を維持している．動物の 運動は多様であり,力学的な観点からその遊泳や飛行挙動 が調べられている(1). 最近では, 地球外惑星探査ロボット の開発，MEMS の技術における設計，小型飛翔体 (MAV) の開発などへの発想や技術革新を求めて, 微小生物や動物 の運動に関する活発な研究が進められている(2). 単細胞生 物の遊泳から鳥の飛行まで, 生物の移動運動を大きさと移 動速度でみると, 遊泳, 歩行, 飛行などの各運動樣式にお いて移動速度は一般に体長とともに増大していく。逆に, 単位重量あたりの運動のエネルギーコストは, 体長ととも に減少する ${ }^{(3)}$. 一般に，レイノルズ数の小さな領域では， 流体の粘性抵抗，生物の表面積，および運動速度が現象を 支配する。レイノルズ数が大きな領域では，抗力は運動す る物体の形状による抗力係数, 流体の密度, 速度の 2 乗, および正面面積に比例する. 端脚目ハマトビムシ科のヒメ 八マトビムシは体長が $10 \mathrm{~mm}$ 前後で，体長の数倍も跳び は衫る動物であり，また，水中で遊泳することもできる. 空気と水では，密度および粘度も大きく異なり，これら2 種類の流体中で巧みな運動を行うハマトビムシはバイオ メカニクスの観点から極めて興味深い生物である(4).

そこで本報は，ハマトビムシの水中での遊泳挙動および 空気中での跳躍挙動を高速度ビデオカメラシステムを用い て詳細に観察し, 力学的な観点からロコモーションのメカ ニズムを考察したものである.

\section{2. 実験装置および方法}

本報で取り扱う試料生物は，節足動物門甲殼綱端脚目八 マトビムシ科に属するヒメハマトビムシである、本実験で 使用した試料八マトビムシは, 潮間帯に生息するありふれ たハマトビムシであり，実験を行う前日あるいは当日，海 辺で採集した。試料八マトビムシの体長はおよそ $5 \mathrm{~mm}$ $10 \mathrm{~mm}$ であり, 多数匹採集し, 比較的活発な個体を選択し て実験に使用した。運動解析実験では，ハマトビムシの自 由跳躍, 自由遊泳, およびテザード遊泳の 3 種類の解析を 行った。跳躍実験では，アクリル平板および発泡スチロー ル平板上にハマトビムシを放つことにより，自由跳躍を行 わせ, 高速度ビデオカメラによって録画し, 録画像を PC 上で解析した。また，遊泳挙動は透明アクリル樹脂で製作 した水容器内（寸法 $58 \mathrm{~mm} \times 54 \mathrm{~mm} \times 7 \mathrm{~mm}$ ) で遊泳を行わ せ, 高速度ビデオカメラによって録画し, PC 上で解析した。 テザード遊泳では，八マトビムシの胸部背側に針を生きた まま接着固定し, 遊泳脚の運動を高速度ビデオ画像を通し て解析した。高速度ビデオの撮影フレームレートは実験に 応じて変えたが， 4000 FPS 以上のコマ数を用いた．また，

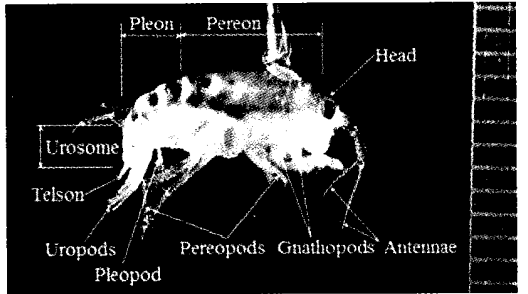

Fig.1 Photograph of beach flea

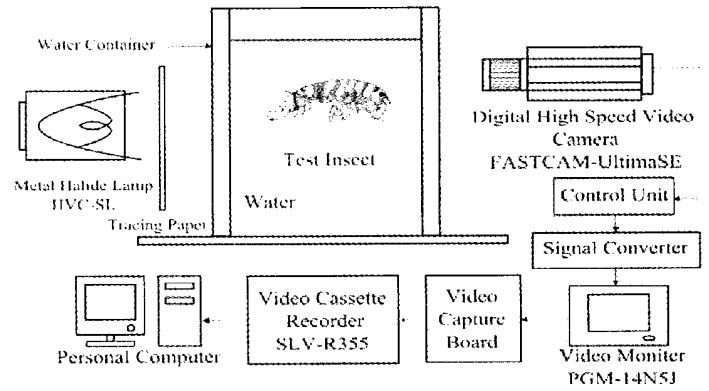

Fig.2 A schematic diagram of experimental apparatus

八マトビムシのテザード遊泳において，試料生物周りの流 れの可視化を行った。可視化におけるトレーサーは，試料 生物の生息している付近で採集した泥粒子を用い水中に混 入し, CW-YAG レーザ $(3 \mathrm{~W}$ ) 光（波長 $\lambda=532 \mu \mathrm{m}$ ) を $0.5 \mathrm{~W}$ でシート状に対象物周りを照射し， $35 \mathrm{~mm}$ カメラによって 撮影することによって行った。図 1 に本報で実験に用いた ハマトビムシの写真を示す．図中にはハマトビムシの体の おもな名称も記入してある。図 2 は本報で構築した実験装 置系の一例であり, 水容器内での遊泳挙動解析実験の概略 図を示している，跳躍実験は，容器部分を平板に換えて実 験を行った。実験はいずれも室内常温下で行った。

\section{3. ハマトビムシの運動におけるレイノルズ数}

運動は動物にとってエネルギーコストの高い行動の 10 であり，それを減らすように進化が進んでいる ${ }^{(5)}$. そのた め動物の移動運動において，流体力学的抵抗を減らすよう な形態や機能が観察される。一般に物体に作用する流体抵 抗は流れのレイノルズ数に依存する。そのため，本報でと りあげたハマトビムシの移動運動におけるレイノルズ数を 考察しておく，後述するが，本報で取りあげたハマトビム シは陸上で通常は歩行するが, 敵からの逃避などの際には, すばやく跳躍する.八マトビムシの歩行は, およそ $11 \mathrm{~mm} / \mathrm{s}$ 程度であり，歩行における力は床面と脚の摩擦によるもの がほとんどであり，流体抵抗は無視し得る。そこで, 跳躍 におけるレイノルズ数 Re を考察する. 八マトビムシは跳 
躍に際して体を回転しながら空中を移動する，そのため， 式 (1) の半径 $R$ の球を仮定し, 運動における $R e$ を求める.

$$
R=\lambda_{B} \frac{2}{3}\left(\frac{L}{2}\right)
$$

ここで $\lambda_{B}$ はハマトビムシの体のアスペクト比, $L$ は体長で ある. 従って, レイノルズ数 Reは

$$
R_{e}=\frac{2 R U_{j}}{v_{a}}=\frac{2 \times 2.05 \times 10^{-3} \times 1.7}{15.1 \times 10^{-6}} \fallingdotseq 4.61 \times 10^{2}
$$

となる．ここで， $v_{a}$ は空気の動粘度， $U_{j}$ は跳躍速度であ る、本報で試料としたハマトビムシは陸生であるが，水中 に入れると巧みに遊泳する，八マトビムシは遊泳時には頭 部を先端として体軸方向にほぼ真直に進む。そ的ため，代 表長さは体幅 $\beta$ を使用して，遊泳におけるレイノルズ数は

$$
R_{e}=\frac{\beta U_{s \max }}{v_{w}}=\frac{3.61 \times 10^{-3} \times 0.11}{1.0 \times 10^{-6}} \fallingdotseq 3.97 \times 10^{2}
$$

になる．ここで， $\nu_{w}$ は水の動粘度， $U_{s \max }$ は遊泳速度の最 大值である. 式（2）と（3）を比較すると，ハマトビムシ は気体中および水中においてほぼ同程度の流れ状態の中に あると言える。

\section{4. 実験結果および考察}

4.1 ハマトビムシの跳躍＼cjkstart前述したようにハマトビ ムシは跳躍できる，ハマトビムシの跳躍時の様態を図 3 に 示す. 図 3 から, 八マトビムシは触覚で地面を確認後, 曲 げていた腹部で地面を蹴って体を上方に投げ上げるように 跳躍している. いま，空気抵抗を無視すると，ハマトビム シの跳躍距離 $S$ は跳躍速度 $U_{j}$ と軌道角 $\theta$ に依存し,

$$
S=\frac{2 U_{j}^{2} \cos \theta \sin \theta}{g}=\frac{U_{j}^{2} \sin 2 \theta}{g}
$$

となる．ここで $g$ は重力加速度である．八マトビムシの筋 肉によって生成されるエネルギ $E$ を用いて, 跳躍速度 $U_{j}$ を記述すると

$$
U_{j}=(2 E / m)^{1 / 2}
$$

となる. 最大跳躍距離は $\theta=\pi / 4$ で得られ, $S$ は式(6)となる.

$$
S=2 E /(m g)
$$

式(6)を用いて，八マトビムシの生成するエネルギ $E$ を求め ることができ，ここでは，E $\fallingdotseq 3.92 \times 10^{-6} \mathrm{~J}$ が得られた。

4.2 ハマトビムシの遊泳前述したようにハマトビ ムシを水中に入れると, 巧みな遊泳を示した. 図 4 は八マ トビムシの自由遊泳時の遊泳速度 $U_{s}$ の変動を示したもの である。この遊泳速度の変動はハマトビムシの遊泳器官の 運動と連動している。すなわち，図 1 に示した遊泳脚 (Pleopods) を漕ぐときに速度が高く, 元の位置に戻す（リ カバリーストローク）ときに低い.すなわちハマトビムシ は一定速度での遊泳ではなく周期的に速度が変動する遊泳 様式を示吉，八マトビムシの遊泳脚は 3 対付属し，それぞ れ左右が二叉し，多数の細毛が生えている．高速度ビデオ 観察の結果，遊泳脚の細毛はパワーストローク時には整列 して開かれ，リカバリーストローク時には折畳まれて戻さ れていた。一例としてテザード状態で, 細毛を開いて脚を 漕いでいる正面写真を図 5 に示す。ハマトビムシはこの脚 漕ぎによって抗力を生成し, 流れを後方に送り, 推進する. 遊泳脚の細毛の長さは $282 \mu \mathrm{m} \sim 614 \mu \mathrm{m}$ であり，細毛間の 間隔はおよそ $83 \mu \mathrm{m}$ であった。これらの数值には流体力学 的理由があると考えられるが，現在は不明である。

ハマトビムシの脚運動によって誘起される流れの可視化 を行った，その結果の一例を図 6 に示す。図 6 から，八マ

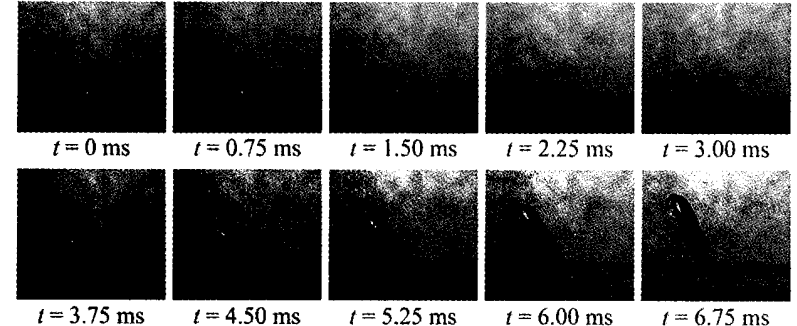

Fig. 3 Framing camera record of beach flea jump

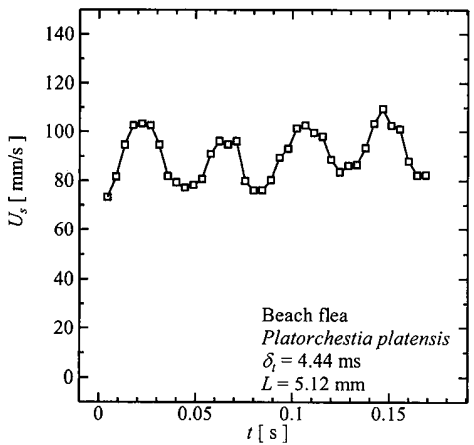

Fig.4 Variation of swimming speed of beach flea

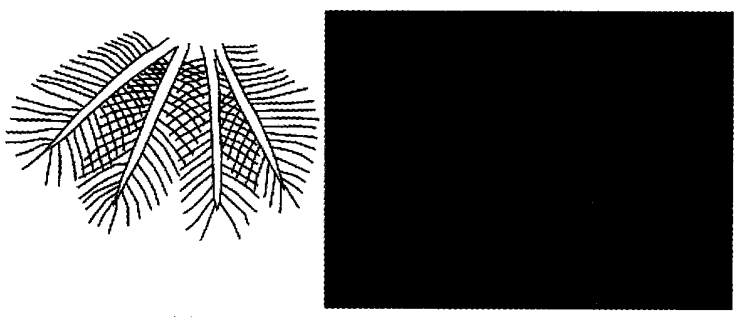

(a)

(b)

Fig.5 Minute hairs in the swimming legs

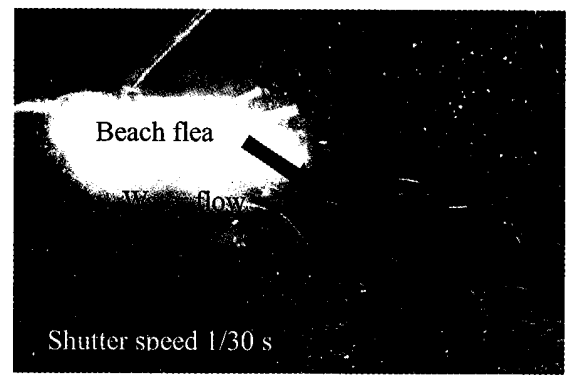

Fig.6 Visualization photograph of flow field

トビムシは遊泳時には跳躍に用いる腹部を真直ぐに伸ばし ていることが明らかである。また，後方に形成された流れ のパターンにふくらみとくびれが観察される.これらは， 3 対の遊泳脚の動きに対応して形成されたものと考えられる。 比較的速い部分の流速はおよそ $0.6 \mathrm{~m} / \mathrm{s}$ 程度である.

\section{5. 結 言}

陸生の節足動物であるハマトビムシの水中での遊泳挙動 および空気中での跳躍挙動を観察し，ロコモーション・メ カニズムの解明を試みた。

\section{文 献}

(1) 東 昭, 生物の動きの事典, 朝倉書店, (2000), 1

(2) Dickinson, M.H., et al., Scinece, 288(2000), 100.

(3) Schmidt-Nielsen, K., Scinece, 177(1972), 222.

(4) 須藤 - 他, 実験力学, 11(2011), 19

(5) Gleiss, A.C. , et al., Nature Comm. , 2:352(2011), DOI:10.1038. 